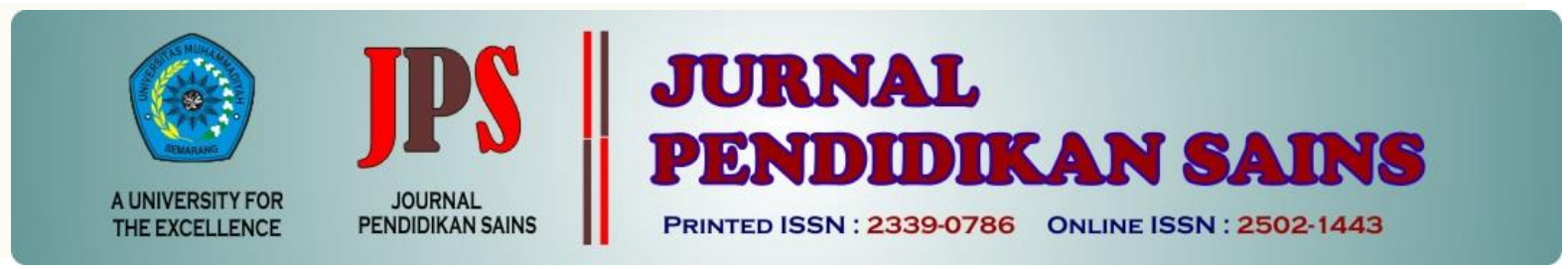

http://jurnal.unimus.ac.id/index.php/JPKIMIA

\title{
KEMAMPUAN PEMECAHAN MASALAH DAN ARGUMENTASI ILMIAH SISWA SMA NEGERI 1 TARAKAN DINAMIKA GERAK ROTASI
}

\author{
Oleh \\ Dady Sulaiman*1, Sentot Kusairi*2 ${ }^{2}$, Eny Latifah ${ }^{2}$ \\ Universitas KALTARA*1, Pendidikan Fisika - Pascasarjana, Universitas Negeri Malang ${ }^{* 2}$
}

\begin{tabular}{|c|c|c|}
\hline \multicolumn{2}{|c|}{ Article history } & Abstract \\
\hline Submission & $: 2019-01-31$ & describe students' argumentation and problem \\
\hline Revised & : 2019-03-17 & solving skills on dynamics rotational motion material. The research \\
\hline Accepted & $: 2019-03-22$ & method is descriptive survey involving 60 students of SMA Negeri 1 \\
\hline \multicolumn{2}{|l|}{ Keyword: } & questions of scientific argument and given 90 minutes to complete. \\
\hline \multicolumn{2}{|c|}{ Kata kunci: } & The average problem solving skill of students is $31.2(41.6 \%)$. The \\
\hline \multicolumn{2}{|c|}{ Kemampuan Pemecahan } & ach indicator is as follows Useful Description \\
\hline \multicolumn{2}{|c|}{ Masalah } & 1.34(26.8\%), Specific Application of Physics 2,3 (46\%), and \\
\hline \multirow{2}{*}{\multicolumn{2}{|c|}{$\begin{array}{l}\text { Argumentasi Ilmiah } \\
\text { Dinamika Gerak rotasi }\end{array}$}} & Mathematical Procedures 2.6 (52\%). The average scientific argument \\
\hline & & $\begin{array}{l}\text { is } 45.5 \text { and the quality of students' scientific argument is only at levels } \\
1-3 \text {. }\end{array}$ \\
\hline
\end{tabular}

\section{Pendahuluan}

Fisika merupakan materi yang sulit untuk dipahami siswa khususnya pada materi dinamika gerak rotasi. Beberapa penelitian sebelumnya menemukan kesulitan siswa pada materi gerak rotasi salah satunya pada artikel Mashod \& Singh (2015) yang menyatakan siswa kesulitan menghubungkan gerak rotasi dan gerak linear. Penyebab siswa kesulitan memahami konsep ini dikarenakan siswa hanya mengingat rumus tanpa memahami konsep yang diberikan oleh guru (Nursaila \& Farida, 2015). Selain itu, siswa masih belum memahami materi-materi sebelumnya seperti pada materi gaya (Nursaila \& Farida, 2015), konsep Newtonian (Close, 2013), konservasi energi, dan materi esensial lainnya. Selain itu kurangnya kemampuan kognitif dan matematika siswa (Ambrosis, 2015) atau kemampuan pemecahan masalah (Hertiavi, 2010) menjadi penyebab siswa kesulitan dalam memahami materi ini.
Kemampuan pemecahan masalah menjadi salah satu kemampuan yang diperlukan oleh siswa, tidak hanya dalam pembelajaran fisika tetapi juga dalam kehidupan sehari - hari. Kemampuan pemecahan masalah merupakan kemampuan dimana siswa tidak hanya memikirkan fakta, menggunakan matematika untuk memecahkan masalah tapi juga memutuskan strategi yang tepat (Nursaila \& Farida, 2015). Kemampuan pemecahan masalah juga membangun proses berpikir kognitif untuk memahami konsep atau masalah yang diberikan (Shute, 2016; Doctor \& Mestre, 2014) serta memfasilitasi siswa dalam membangun pengetahuan baru (Ryan, 2016) dan melatih penalaran matematis (Hertiavi, 2010). Oleh karena itu, kemampuan ini merupakan kemampuan yang esensial tidak hanya dalam pembelajaran (Doctor, 2015; 2013), tapi juga dalam kehidupan sehari - hari (Ryan, 2016; Shute, 2016; Doyan \& Sukmantara, 2014).

*Corresponding Author:

$\begin{array}{ll}\text { Nama } & \text { : Dady Sulaiman } \\ \text { Lembaga } & \text { : Universitas Kaltara } \\ \text { Email } & \text { : dadysulaiman92@gmail.com }\end{array}$


Berikut beberapa penelitian mengenai kemampuan pemecahan masalah. Seperti penelitian mengenai penggunaan media untuk menilai pemecahan masalah (Shute, 2016; Ryan, 2016). Kemudian Doctor pada artikelartikelnya mengembangkan rubrik untuk menilai kemampuan pemecahan masalah (Docktor, 2016). Selain itu artikel lainnya membahas mengenai strategi (Nursaila \& Farida, 2015) dan pendekatan berbasis pemecahan masalah atau Conceptual problem solving dalam pembelajaran fisika (Doctor, 2015).

Selain kemampuan pemecahan masalah, kemampuan argumentasi ilmiah juga perlu untuk dimiliki oleh siswa. Beberapa artikel bidang pendidikan menerapkan argumentasi ilmiah ini dalam pembelajaran sains (Wang \& Buck, 2016; Hasnunidah, 2015; Heitmann, 2014; Khishfe, 2014). Selain itu (Park, 2016; Siswanto, 2014) dalam artikelnya mengatakan kemampuan ini dapat membantu siswa untuk memahami konsep sains. Karena dalam pembelajaran yang menekankan argumentasi ilmiah di dalamnya, siswa dapat membangun pengetahuan yang baru (Nichols, 2013; Khishfe, 2014; Suhandi, 2012; Siswanto, 2014), melatih kemampuan penalaran (Suhandi, 2012), melatih kompetensi ilmiahnya (Tsai 2015), dan dapat membantu siswa dalam membuat keputusan dan memecahkan masalah (Rebello \& Rebello, 2012). Di luar kelas siswa juga dapat menggunakan kemampuan ini dalam kehidupan bersosialisasinya (Heitmann, 2014).

$$
\text { Meskipun banyak penelitian }
$$

sebelumnya yang menekankan pentingnya kemampuan pemecahan masalah dan argumentasi ilmiah siswa, masih banyak penelitian yang menyatakan kemampuan ini masih kurang dimiliki siswa. Kurangnya kemampuan pemecahan masalah siswa dapat dilihat dari kecendrungan siswa mengingat prosedur dari masalah-masalah yang sebelumnya tanpa memahami konsep yang digunakan (Nursaila \& Farida, 2015) serta kurangnya penelitian mengenai cara menilai kemampuan pemecahan masalah (Adam \& Wieman, 2007). Sementara untuk kemampuan argumentasi imiah, kurangnya kemampuan ini dapat dilihat dari kurangnya penerapan pembelajaran berbasis argumentasi (Suhandi, 2012; Hasnunidah, 2015). Hal ini membuat siswa kesulitan membuat klaim dengan data atau bukti yang kuat (Berland \& McNeil, 2010; Siswanto, 2014)

Kemampuan pemecahan masalah dan argumentasi ilmiah merupakan kemampuan yang perlu dimiliki siswa. Berdasarkan artikel - artikel sebelumnya menyatakan bahwa terdapat hubungan antara kedua kemampuan ini atau dengan kata lain dengan mengembangkan kemampuan argumentasi ilmiah dapat mengembangkan kemampuan pemecahan masalah begitupun sebaliknya. Karena ditemukan kurangnya kemampuan pemecahan masalah dan argumentasi ilmiah siswa pada beberapa penelitian, penelitian ini dilakukan dengan tujuan untuk mengetahui bagaimana kemampuan pemecahan masalah dan argumentasi ilmiah siswa SMA Negeri 1 Tarakan pada materi dinamika gerak rotasi. Serta untuk mengetahui apakah kemampuan pemecahan masalah dan argumentasi ilmiah saling berhubungan atau tidak. Hasil penelitian ini dapat dijadikan rujukan untuk penelitian selanjutnya dalam mengatasi kurangnya kemampuan pemecahan masalah dan argumentasi ilmiah siswa sehingga siswa tidak kesulitan dalam memahami konsep fisika.

\section{Metode Penelitian}

Jenis penelitian yang digunakan adalah deskriptif survey. Penelitian deskriptif survey bertujuan untuk menjelaskan atau mendeskripsikan suatu keadaan atau fenomena, dimana pada penelitian ini adalah kemampuan pemecahan masalah dan argumentasi ilmiah siswa pada materi dinamika gerak rotasi di SMA Negeri 1 Tarakan. Sampel penelitian ini 60 siswa kelas XI IPA SMA N 1 Tarakan yang terbagi menjadi 2 kelas. Metode pengumpulan data adalah dengan menggunakan tes. Tes adalah kumpulan butir soal yang digunakan untuk mengukur suatu variabel atau keadaan.

Soal kemampuan pemecahan masalah yang digunakan adalah 5 soal berbentuk essay yang diadaptasi dari (Serway \& Jewett, 2014) dan diukur menggunakan rubrik pemecahan masalah (Doctor, 2016) yang disesuaikan dengan jawaban siswa seperti pada Gambar 2. Soal argumentasi ilmiah diadaptasi dari (Wang \& Buck, 2014) yang terdiri dari satu soal untuk menilai pendapat siswa dan satu soal untuk mengukur bagaimana siswa menanggapi pendapat lainnya. Penilaian argumentasi ilmiah siswa menggunakan skoring seperti pada Tabel 1 berikut, dimana semakin tinggi 
skornya semakin tinggi kualitas argumentasi ilmiah siswa (Sampson, 2011). Gambar 1 berikut menunjukkan salah satu jawaban siswa yang memiliki kualitas argumentasi dengan skor 3 pada soal pertama dan skor 4 untuk soal kedua.

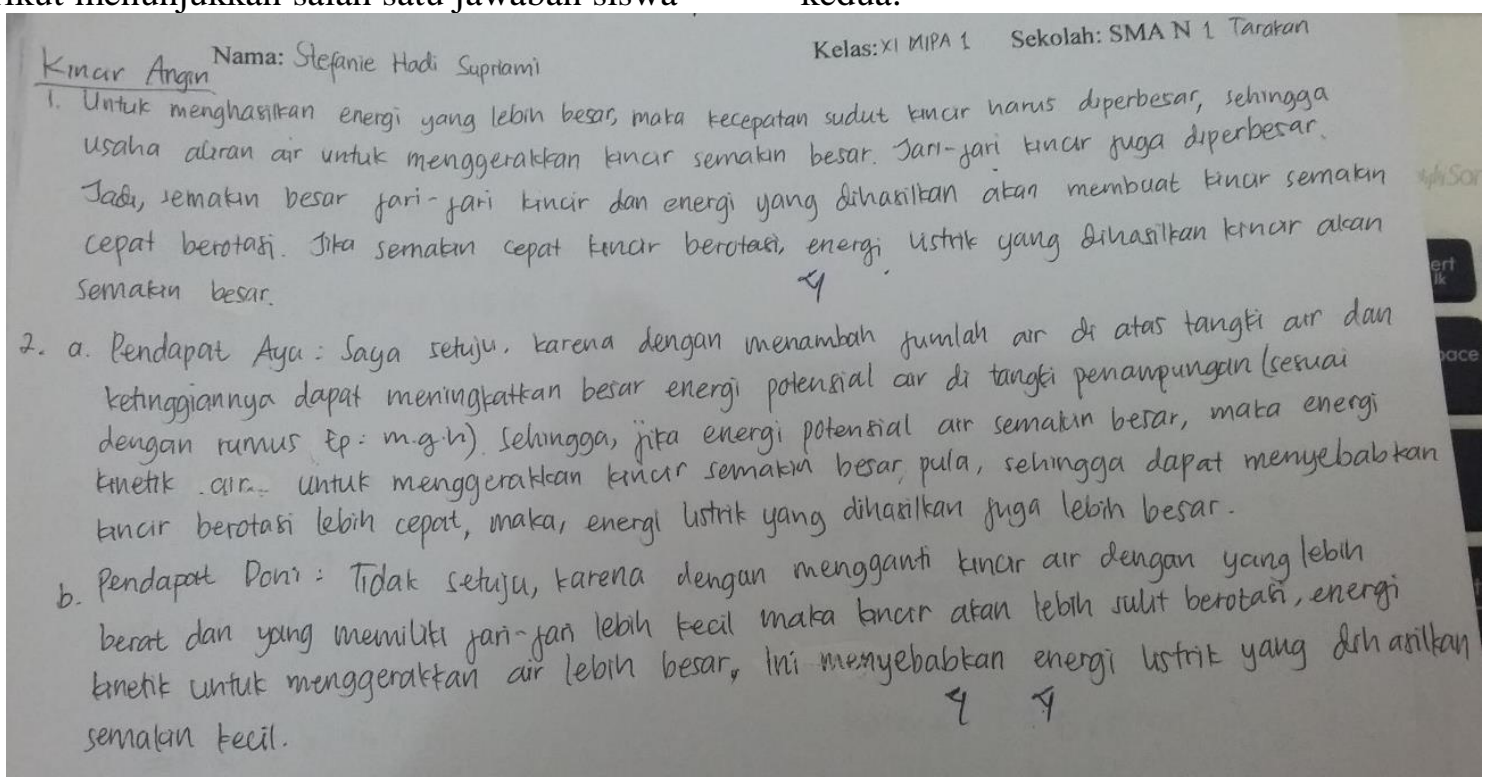

Gambar 1. Contoh skoring jawaban argumentasi ilmiah siswa

Tabel 1. Rubrik skor argumentasi ilmiah (Demircioglu \& Ucar, 2015)

Skoring soal no $1 \quad$ Skoring soal no 2

0: pernyataan berisi klaim yang tidak sesuai dengan kunci

1: pernyataan hanya berisi klaim tanpa didukung dengan bukti

2: pernyataan berisi lebih dari satu klaim tanpa didukung dengan bukti

3. pernyataan berisi satu atau lebih klaim dan didukung dengan bukti yang jelas

4: pernyataan berisi klaim, didukung bukti dan rasional yang menggunakan pendekatan fisika.
0: Pernyataan setuju dan tidak setuju tidak sesuai dengan kunci jawaban

1: hanya pernyataan setuju dan tidak setuju tanpa disertai alasan

2: hanya salah satu pernyatan (setuju atau tidak setuju) disertai dengan klaim atau alasan 3: pernyatan setuju dan tidak setuju disertai dengan klaim atau alasan

4: pernyatan setuju dan tidak setuju disertai dengan klaim atau alasan serta penjelasan rasional secara fisika 
Hasil tes kemampuan pemecahan masalah dan argumentasi ilmiah siswa dikorelasikan untuk mengetahui hubungan antara kemampuan pemecahan masalah dan argumentasi ilmiah siswa dengan tingkat korelasi dan kekuatan hubungan ditunjukkan pada tabel 2. Kemudian dengan membandingkan $t_{\text {hitung }}$ dengan $t_{\text {tabel }}$ untuk mengetahui apakah ada hubungan yang signifikan atau tidak.

\section{Hasil Penelitian dan Pembahasan}

Gambar 1 merupakan salah satu contoh jawaban siswa yang menggambarkan cara siswa memecahkan masalah atau indikator yang diukur dalam penelitian ini. Dapat dilihat bahwa jawaban untuk siswa terdiri dari tiga indikator kemampuan pemecahan masalah. Indikator yang terdapat pada Gambar 1 tersebut adalah Useful Description, Spesific Application of Physics, dan Mathematical Procedures. Useful Description pada jawaban menilai deskripsi
Tabel 2. Interpretasi koefisien Korelasi

\begin{tabular}{ccc}
\hline No & Korelasi $(\boldsymbol{r})$ & Tingkat hubungan \\
\hline 1 & $0,00-0,19$ & Sangat lemah \\
\hline 2 & $0,20-0,39$ & Lemah \\
\hline 3 & $0,40-0,59$ & Cukup \\
\hline 4 & $0,60-0,79$ & Kuat \\
\hline 5 & $0,80-0,99$ & Sangat kuat \\
\hline & & (Siregar, 2015)
\end{tabular}

yang digunakan untuk memecahkan masalah seperti keterangan gambar dan besaran besaran yang digunakan. Indikator Spesific Application of Physics menilai kebenaran rumus dan satuan yang digunakan. Karena pada gambar tersebut siswa tidak mencantumkan satuan, maka nilai untuk indikator ini hanya 4. Sementara untuk indikator terakhir Mathematical Procedures menilai kebenaran solusi berdasarkan matematikanya, dimana tidak ada kesalahan dalam perhitungan ditemukan pada jawaban tersebut sehingga nilai untuk indikator ini adalah 5

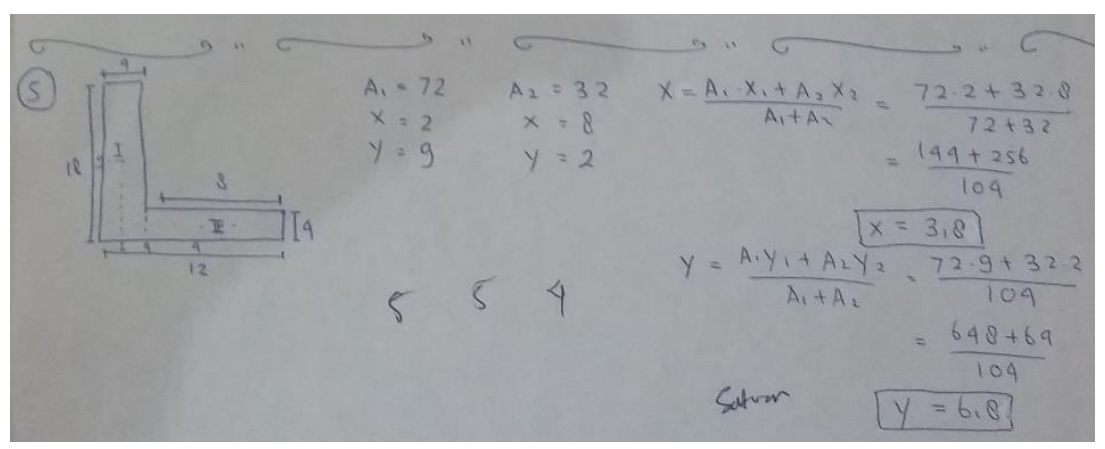

Gambar 2 Contoh jawaban tes kemampuan pemecahan masalah no 5 materi titik berat

Nilai rata - rata kemampuan pemecahan masalah siswa SMA N 1 Tarakan pada materi Dinamika gerak rotasi adalah 31,2 $(41,6 \%)$. Dimana hasil analisis per indikator pemecahan masalah siswa adalah sebagai berikut. Dari nilai maksimal 5 per indikator soal diperoleh rata - rata Useful Description 1,34 (26,8\%), Spesific Application of Physics 2,3 (46\%), dan Mathematical Procedures 2,6 (52\%). sedangkan untuk analisis item soal dapat dilihat pada Gambar 3. 


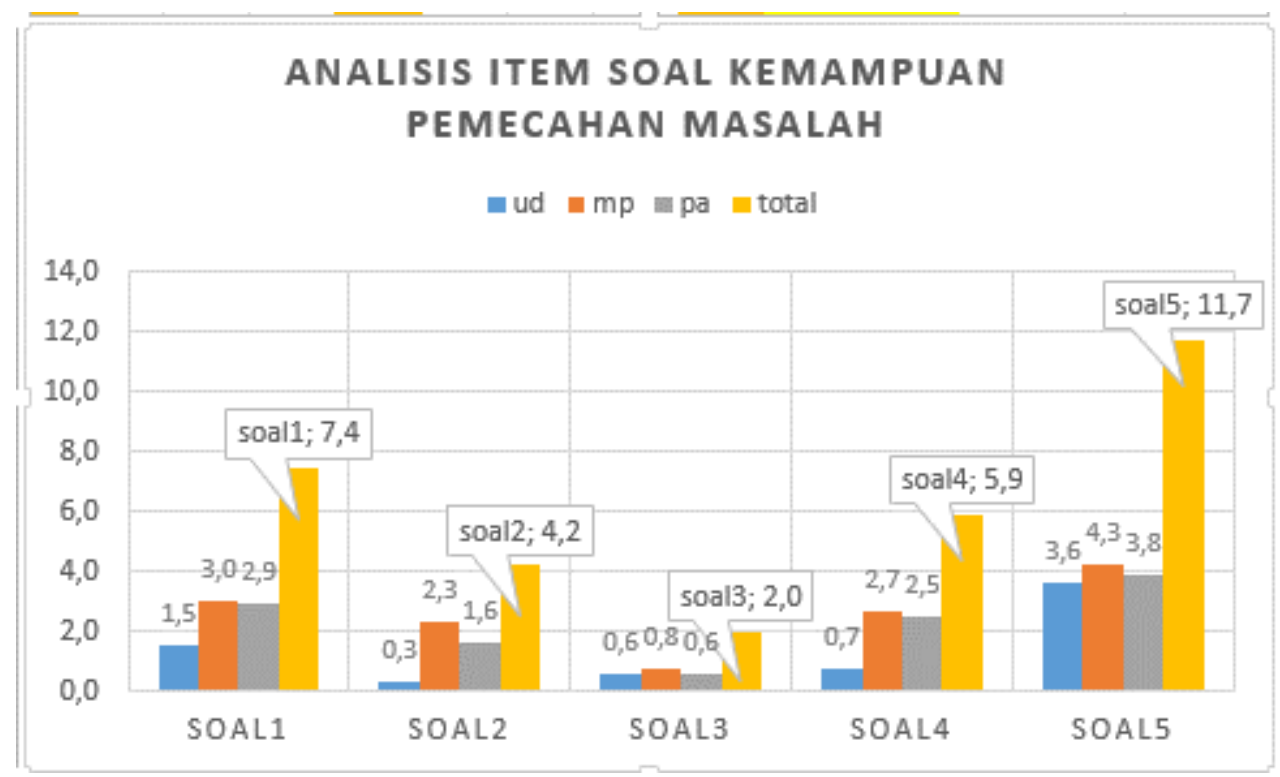

Gambar 3. Grafik analisis item soal kemampuan pemecahan masalah

Berdasarkan gambar 3 diatas, untuk indikator Useful Description siswa kurang pada soal no 2, 3, dan 4 . Nilai rata - rata siswa tertinggi terdapat pada soal no 5 dan yang terendah pada soal no 3 atau dapat kita interpretasikan siswa kesulitan mengerjakan soal no 3 yaitu mengenai penerapan hukum kekekalan momentum sudut seperti pada gambar 4 berikut. Sementara untuk materi titik berat pada soal no 5 siswa tidak kesulitan.

\section{Soal no 3}

Sebuah balok dengan massa 2kg dihubungkan dengan sebuah batang yang memiliki panjang $30 \mathrm{~cm}$ dan massanya diabaikan seperti pada gambar.

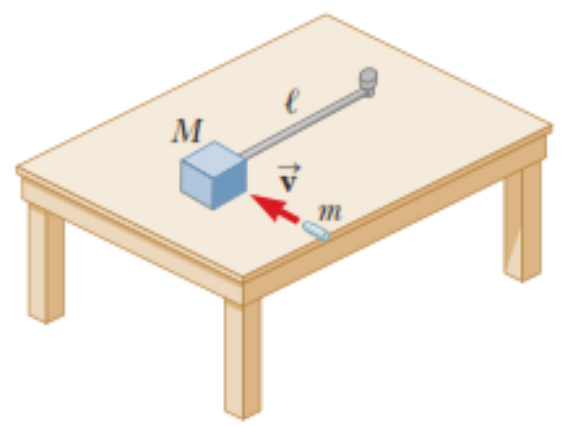

Kemudian kearah balok ditembakkan peluru yang bermassa $20 \mathrm{gr}$ dengan kecepatan $200 \mathrm{~m} / \mathrm{s}$ yang kemudian menyatu dengan balok tersebut. Jika arah peluru sejajar dengan bidang (meja) dan tegak lurus terhadap batang tak bermassa. Berapakah kecepatan akhir sistem setelah peluru terebut menyatu dengan balok.
Soal no 5

Nia memiliki penggaris berbentuk L seperti pada gambar.

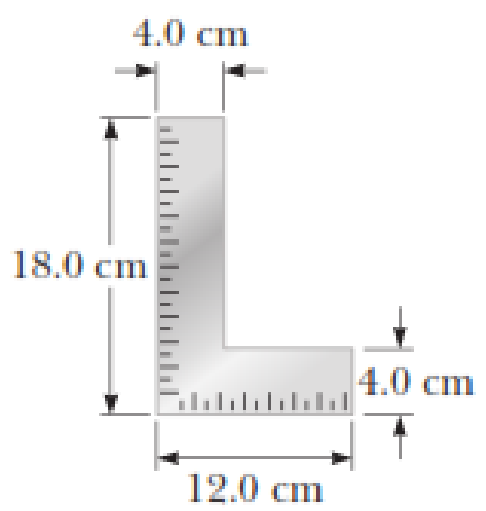

Tentukan lokasi titik berat penggaris tersebut?

Gambar 4. Soal no 3 dan 5 
Hasil rata - rata argumentasi ilmiah siswa SMA N 1 Tarakan pada materi dinamika gerak rotasi adalah 45,5. Dimana untuk soal no 1 yang menilai bagaimana argumen siswa dalam menyelesaikan masalah kincir air yang diberikan rata - rata nilai pendapat siswa adalah 1,7. Hanya 2 atau 3\% siswa yang memberikan argumen disertai alasan yang ilmiah atau alasan yang berisi data, bukti dan penalaran yang sesuai dengan konsep fisika. Sementara untuk soal no 2 rata - rata siswa hanya memberikan alasan untuk pernyataan setuju saja. Hanya sebagian kecil siswa yang memberikan alasan disertai penalaran yang menghubungkan data dan klaim.

Hasil korelasi antara kemampuan pemecahan masalah dan argumentasi ilmiah siswa setelah dianalisis menggunakan korelasi Pearson Product Moment adalah 0,246. Nilai korelasi ini sesuai dengan tabel 1 tergolong lemah. Kemudian, karena nilai $t_{\text {hitung }}<$ $t_{\text {tabel }}$ yaitu 1,95 $<2,021$ dapat diambil kesimpulan tidak terdapat hubungan yang signifikan antara kemampuan pemecahan masalah argumentasi siswa kelas XI SMA N 1 Tarakan pada materi Dinamika gerak rotasi. Sehingga peningkatan kemampuan pemecahan masalah siswa tidak mempengaruhi argumentasi ilmiah siswa dan begitupun sebaliknya.

Setelah dilakukan survey pada 61 siswa diperoleh hasil rata - rata nilai siswa perindikator adalah sebagai berikut. Useful Description 1,34 (26,8\%), Spesific Application of Physics 2,3 (46\%), dan Mathematical Procedures 2,6 (52\%). Dari hasil tersebut dapat kita ambil kesimpulan bahwa siswa sangat kurang dalam memberikan deskripsi yang berguna atau tidak menuliskan apa saja yang diketahui dari soal. Dalam menyelesaikan masalah, indikator atau kemampuan ini diperlukan oleh siswa dalam memecahkan masalah selain itu dengan memberikan keterangan apa saja variabel yang diketahui dapat mengurangi kemungkinan human error dalam menyelesaikan masalah. Sementara untuk indikator Spesific Application of Physics dan Mathematical Procedures rata - rata nilai siswa termasuk kategori sedang. Hasil penelitian ini sejalan dengan beberapa penelitian sebelumnya, seperti penelitian Doyan \& Sukmantara (2014) yang menerapkan pembelajaran berbasis web intranet dan menemukan hasil kemampuan pemecahan masalah dalam kategori sedang. Penelitian lainnya menyatakan kemampuan pemecahan masalah siswa yang tinggal di sekolah asrama tergolong rendah (Dusek \& Ayhan, 2014).

Indikator Useful Description memiliki persentase paling rendah, Hal ini dikarenakan siswa terbiasa mengerjakan soal tanpa menuliskan deskripsi - deskripsi penting yang ada pada soal. Indikator ini merupakan salah satu hal penting dalam memecahkan suatu permasalahan, kurangnya indikator ini dapat mempengaruhi indikator lainnya. Sementara persentase paling tinggi berada pada indikator Mathematical Procedure, rata - rata jawaban siswa mengandung rumus matematika yang diperlukan dalam penyelesaian soal. Meskipun begitu siswa masih mengalami kesulitan dalam menyelesaikannya seperti yang diperlihatkan pada gambar 2.

Argumentasi ilmiah memegang peran penting dalam pembelajaran sains. Argumentasi ilmiah merupakan pendekatan yang sesuai digunakan dalam pembelajaran berbasis inquiry (Wang \& Buck, 2016). Mengajarkan argumentasi ilmiah dapat membantu menjelaskan beberapa fenomena yang kompleks dengan jelas (Nichols, 2015). Selain itu juga dapat memperdalam atau mengembangkan pemahaman konseptual siswa (Wang \& Buck, 2016; Nichols, 2015). Pentingnya kemampuan argumentasi ilmiah ini tidak sesuai dengan hasil penelitian ini dimana kemampuan siswa dalam membuat argumentasi ilmiah masih kurang. Hasil untuk argumentasi ilmiah, hanya 2 siswa saja yang memberikan argumen yang disertai data, bukti, dan rasional sementara kebanyakan atau sekitar $30 \%$ siswa hanya memberikan pendapat tanpa disertai data atau bukti yang mendukung pendapatnya tersebut. Hal ini menunjukkan argumentasi ilmiah siswa masih lemah atau kurang sehingga perlu dilatih atau diajarkan lagi lebih lanjut. Hasil penelitian ini juga ditemukan dalam penelitian Sondang dan Muslim yang menyatakan argumentasi ilmiah siswa masih kurang (Siswanto, 2014)

Kurangnya argumentasi ilmiah ini dapat disebabkan oleh beberapa hal seperti kurangnya penerapan argumentasi ilmiah dalam pembelajaran sains (Park, 2016; Hasnunidah, 2015), kurangnya pemahaman guru fisika itu sendiri mengenai argumentasi ilmiah atau bagaimana membuat argumentasi 
ilmiah yang baik sementara peran guru dalam pembelajaran sangat besar (Wang \& Buck, 2016; Nichols, 2015). Sementara Faktor faktor yang dapat menjadi penyebab kurangnya kemampuan pemecahan masalah siswa adalah penyalahgunaan teknologi (Rodzalan \& Saat, 2015) seperti penggunaan HP untuk mencari jawaban di internet tanpa memikirkan solusinya sendiri dan kurangnya penelitian mengenai cara menerapkan dan menilai kemampuan ini (Adam \& Wieman, 2007)

Sesuai hasil yang disampaikan diatas, dapat diambil kesimpulan bahwa kemampuan pemecahan masalah dan argumentasi ilmiah siswa masih kurang. Oleh karena itu siswa perlu diberi pembelajaran yang dapat meningkatkan kemampuan ini salah satunya adalah pembelajaran dengan model Argument Driven Inquiry dimana beberapa penelitian mengatakan bahwa model ADI ini terbukti dapat meningkatkan kemampuan argumentasi ilmiah dan pemecahan masalah siwa serta dapat membantu siswa memahami konsep lebih baik lagi.

Penelitian ini memiliki kekurangan yakni, sampel penelitian yang digunakan sudah mempelajari materi dinamika gerak rotasi pada semester satu atau sekitar 6 bulan sebelumnya. selain itu karena waktu yang diberikan untuk mengerjakan soal kemampuan pemecahan masalah dan argumentasi ilmiah kurang sehingga siswa terburu - buru dan banyak jawaban yang kosong. Sementara kelebihan pada penelitian ini adalah sebagai berikut. Walaupun siswa telah mempelajari materi ini 6 bulan sebelumnya tapi pemahaman siswa mengenai materi ini masih baik. Selain itu siswa mengerjakan soal dengan sungguh - sungguh meskipun mengetahui tes yang diberikan tidak mempengaruhi nilai raport mereka.

Berdasarkan kekurangan - kekurangan pada penelitian ini, maka untuk penelitian selanjutnya dapat dilakukan beberapa hal ini. (1) menggunakan sampel yang baru saja mempelajari materi penelitian sehingga pemahaman siswa masih baik, (2) pengerjaan soal kemampuan pemecahan masalah dan argumentasi ilmiah diberikan pada waktu yang berbeda sehingga siswa bisa fokus pada salah satu tes tersebut dan tidak terburu - buru mengerjakannya

\section{Simpulan dan Saran}

Simpulan

Berdasarkan hasil pembahasan sebelumnya bahwa kemampuan pemecahan masalah dan argumentasi ilmiah siswa SMA Negeri 1 Tarakan pada materi Dinamika gerak rotasi masih kurang. Ada banyak faktor yang mungkin dapat menyebabkan kurangnya kemampuan ini, seperti siswa belum memahami konsep dinamika gerak rotasi, soal yang digunakan belum disesuaikan dengan kemampuan siswa, kurangnya pemahaman guru mengenai kemampuan ini atau bisa juga karena guru tidak mengetahui cara menilai kemampuan pemecahan masalah dan argumetasi ilmiah siswa.

Saran

Karena itu untuk mengatasi ini peneliti menyarankan untuk penelitian selanjutnya membahas bagaimana cara menilai kemampuan - kemampuan ini serta pembelajaran yang seperti apa yang sesuai untuk meningkatkan kemampuan kemampuan ini. Salah satu pembelajaran yang disarankan adalah Argument Driven Inquiry .

\section{DAFTAR RUJUKAN}

Adams, W. K., \& Wieman, C. E. 2007. Problem solving skill evaluation instrument-validation studies. In $A I P$ Conference Proceedings (Vol. 883, pp. 18-21).

Ambrosis, A. De, Malgieri, M., Mascheretti, P., \& Onorato, P. 2015. Investigating the role of sliding friction in rolling motion: a teaching sequence based on experiments and simulations. European Journal of Physics, 36(3), 35020.

Berland, L. K., \& McNeill, K. L. 2010. A learning progression for scientific argumentation: Understanding student work and designing supportive instructional contexts. Science Education, 94(5), 765-793.

Close, H. G., Gomez, L. S., \& Heron, P. R. L. 2013. Student understanding of the application of Newton's second law to rotating rigid bodies. American Journal of Physics, 81(6), 458-470.

Docktor, J. L., \& Mestre, J. P. 2014. Synthesis of discipline-based education research in physics. Physical Review Special Topics 
- Physics Education Research, 10(2), 158.

Docktor, J. L., Dornfeld, J., Frodermann, E., Heller, K., Hsu, L., Jackson, K. A., ... Yang, J. 2016. Assessing student written problem solutions: A problem-solving rubric with application to introductory physics. Physical Review Physics Education Research, 12(1), 1-18.

Docktor, J. L., Strand, N. E., Mestre, J. P., \& Ross, B. H. 2015. Conceptual problem solving in high school physics. Physical Review Special Topics - Physics Education Research, 11(2), 1-13.

Doyan, A., \& Sukmantara, I. K . 2014. Pengembangan Web Intranet Fisika Untuk Meningkatkan Kemampuan Pemecahan Masalah Siswa SMK. Jurnal Pendidikan Fisika Indonesia (Indonesian Journal of Physics Education), 10(2), 117-127.

Hasnunidah, N., Susilo, H., Irawati, M. H., \& Sutomo, H. 2015. Argument-Driven Inquiry with Scaffolding as the Development Strategies of Argumentation and Critical Thinking Skills of Students in Lampung , Indonesia. American Journal of Educational Research, 3(9), 1185-1192.

Heitmann, P., Hecht, M., Schwanewedel, J., \& Schipolowski, S. 2014. Students' Argumentative Writing Skills in Science and First-Language Education: Commonalities and differences. International Journal of Science Education, 36(18), 3148-3170.

Hertiavi, M. A., Langlang, H., \& Khanafiyah, S. 2010. Penerapan model pembelajaran kooperatif tipe jigsaw untuk peningkatan kemampuan pemecahan masalah siswa smp. Jurnal Pendidikan Fisika Indonesia (Indonesian Journal of Physics Education), 6, 53-57.

Khishfe, R. 2014. Explicit Nature of Science and Argumentation Instruction in the Context of Socioscientific Issues: An effect on student learning and transfer. International Journal of Science Education, 36(6), 974-1016.

Mashood, K. K., \& Singh, V. A. 2015. Rotational kinematics of a rigid body about a fixed axis: development and analysis of an inventory. European Journal of Physics, 36, 1-20.
Nichols, K., Gillies, R., \& Hedberg, J. 2015. Argumentation-Based Collaborative Inquiry in Science Through Representational Work: Impact on Primary Students' Representational Fluency. Research in Science Education, 343-364.

Nusaila, Siti \& Farida. 2015. Problem Solving Strategy in Balanced Forces. International Journal of Business and Social Science, 6(8), 94-98.

Park, S. K. 2016. Exploring the argumentation pattern in modeling-based learning about apparent motion of Mars. Eurasia Journal of Mathematics, Science and Technology Education, 12(1), 87-107.

Rebello, C. M., \& Rebello, N. S. 2013. Transfer of argumentation skills in conceptual physics problem solving Transfer of Argumentation Skills in Conceptual Physics Problem Solving. Physics Education Research Conference, 322.

Rodzalan, S. A., \& Saat, M. M. 2015. The Perception of Critical Thinking and Problem Solving Skill among Malaysian Undergraduate Students. Procedia Social and Behavioral Sciences, 172(2012), 725-732.

Ryan, Q. X., Frodermann, E., Heller, K., Hsu, L., \& Mason, A. 2016. Computer problem-solving coaches for introductory physics: Design and usability studies. Physical Review Physics Education Research, 12(1), 10105.

Sampson, V., Grooms, J., \& Walker, J. P. 2011. Argument-Driven Inquiry as a way to help students learn how to participate in scientific argumentation and craft written arguments: An exploratory study. Science Education, 95(2), 217-257.

Serway Raymond A. \& Jewett, John W. Jr. 2014. Physics for Scientists and Engineers with Modern Physics, Ninth Edition. USA: BROOKS/COLE CENGAGE Learning

Shute, V. J., Wang, L., Greiff, S., Zhao, W., \& Moore, G. 2016. Computers in Human Behavior Measuring problem solving skills via stealth assessment in an engaging video game. Computers in Human Behavior, 63, 106-117.

Siregar, Syofian. 2015. Statistika Terapan Untuk Perguruan Tinggi. Jakarta: PRENADAMEDIA GROUP 
Siswanto, Kaniawati, I., \& Suhandi, A. 2014. PENERAPAN MODEL PEMBELAJARAN PEMBANGKIT IMPLEMENTATION OF GENERATE ARGUMENT INSTRUCTIONAL MODEL USING SCIENTIFIC METHOD TO INCREASE THE COGNITIVE ABILITIES AND. Jurnal Pendidikan Fisika Indonesia (Indonesian Journal of Physics Education), 10(2), 104-116.

Suhandi, A. 2012. PENGEMBANGAN PERANGKAT PEMBELAJARAN FISIKA DAN KEMAMPUAN BERARGUMENTASI CALON GURU FISIKA. Jurnal Pendidikan Fisika
Indonesia (Indonesian Journal of Physics Education), 8, 174-183.

Tsai, C.-Y. 2015. Improving Students' PISA Scientific Competencies Through Online Argumentation. International Journal of Science Education, 37(2), 321-339.

Wang, J., \& Buck, G. 2014. The Relationship Between Chinese Students' Subject Matter Knowledge and Argumentation Pedagogy. International Journal of Science Education, 37, 340-366.

Wang, J., \& Buck, G. A. 2016. Understanding a High School Physics Teacher' $\mathrm{s}$ Pedagogical Content Knowledge of Argumentation. Journal of Science Teacher Education, 27(5), 577-604. 